\title{
Economic Agreements in the Yugoslav-Albanian Relations
}

\author{
Phd candidate Ornela Shameti
}

\author{
Dr. Pranvera Dibra
}

History and Geography nelashameti@yahoo.com

Doi:10.5901/mjss.2014.v5n13p289

\begin{abstract}
During 1945-1947, the foreign politics policy of Albania moved towards an intense relation with Yugoslavia. The main interest of Belgrade was to include Albania in the Balkan Federation. In July 1946 the two countries signed the tract of Friendship and Reciprocal help which opened the doors to a union between them. During this period Albania and Yugoslavia signed several economic agreements such as: the Economic Convention, Treaty on trade exchanges and their payments, Economic cooperation Treaty, Accordance for the establishment of the Albanian-Yugoslav society for the exploration and exploitation of the mines, Accordance for the establishment of the Albanian-Yugoslav Bank, Agreement of 2 billion dinars credit for the recovery of the Albanian economy, Unification of Prices, Agreement on Customs Union etc. To keep the political power, Enver Hoxha was required to come to an agreement with Yugoslavia but he was not willing to share the power with them or their instruments in Albania. Political disagreements between Tito-Stalin in 1948 were the perfect occasion for Enver Hoxha to end the relationship with Yugoslavia and to take out of the political area Koci Xoxe who was his opponent and a declared Yugoslavia supporter. After this situation in Albania started the prosecution of the pro Yugoslavia groups inside Albania Communist Party leaded by Koci Xoxe who was sentenced with death penalty whereas his collaborators were sentenced with several minor charges. Separation from Yugoslavia saved Albania from a complete economical and political annexation.
\end{abstract}

\section{Economic Agreements in the Yugoslav-Albanian Relations}

During the Second World War, Albania and Yugoslavia were victims of the fascist Italy and Nazi Germany's aggression. This situation encouraged the anti-fascist resistance forces in both countries. Thus, collaboration between the communist parties of the two countries became stronger. Communist Party of Yugoslavia (CPY), as an older political force, had a direct impact on the process for the foundation of the Albanian Communist Party. Hence, CPY had a privileged position in the relations with the leaders of the Communist Party Albania (CPA).

The postwar situation charged CPA, which gained political power in the country, with quite difficult tasks and responsibilities. It had to rebuild the country which was totally devastated by war and develop the economy of the country. In the new geopolitical conditions created after the Second World War, after the fall of Italy as a competitive power towards the Yugoslav interests in Albania before the War, the Communist Party of Yugoslavia, already in power and with a strong influence on the Albanian Communist Party which had just taken the power, had a free hand in specifying its own interests in Albania.

However, during 1945, the relations between these two countries were mainly focused on the political and diplomatic fields and less in economic ones. Meanwhile, Stalin-Churchill's accordance, in October 1944, did not mention anything as regards the role of Albania in the sphere of influences game. This meant a free hand for political and economic interference of the Yugoslav government into the internal affairs of Albania.

In general, Yugoslav-Albanian relations in the period1945-1948 were characterized precisely by a well defined policy of CPY, which had a final goal-incorporating the independent Albanian state within the borders of Yugoslavia and making it the seventh republic of the Yugoslav Federation. This undeniable character of the Yugoslav policy was distorted by the leader of CPA and prime minister of those years Enver Hoxha as well as by all the historiography of the communist period, by considering it an "hostile Yugoslav interference in the internal affairs of Albania". Actually, the Yugoslav political and economic imposition onto Albania, found a supportive positive ground at the leaders of Albanian state of that period (Plasari \& Malltezi, 1996).

The Yugoslav interference and pressure on the new Albanian state made the country's political elite to steer the country towards Communist East, despite the opportunities it had to be oriented towards the West, thanks to the international circumstances and geostrategic position of the country.

In the 5-th Plenum of the Central Committee of CPA, Enver Hoxha clearly manifested the unconditional orientation 
of Tirana toward Belgrade. According to him, the country should breed the love toward Yugoslavia. During 1946, the press was full of pro-Yugoslav propaganda ( General Directorate of Archives, 1996).

This situation was evolving parallel to the great economic need that Albania had after the War. In its foreign policy, during 1945-1947, the communist government of Tirana was oriented toward an increasingly approach with Yugoslavia. This offered a great opportunity to the official Belgrade, which didn't want to be a committed satellite of Moscow in its targets in the region, but it intended to create the Balkan Federation under the direction of Yugoslavia, Albania being the seventh republic of it.

The Yugoslav-Albanian relations became much closer after the visit that Enver Hoxha paid in Yugoslavia, on $23^{\text {rd }}$ June to $2^{\text {nd }}$ July, 1946. The Economic Cooperation Agreement between the two countries was signed. According to this agreement, there would be created the common Yugoslav-Albanian associations for a period of 30 years, in the fields of construction and utilization of the railways, in oil extraction and procession, in excavation of minerals and exploitation of metals, in electrification, in the naval transport, in the import-export as well as in the creation of the Yugoslav-Albanian banks (Hoxha, 2013). In the same issue "Luftetari" newspaper carries on: "By creating these joint associations, Yugoslavia would assist through investments that would help in increasing the production, which was not only our interest but also Yugoslavia and the entire unique socialist camp's interest. However, the core purpose of the Yugoslav nationalist leadership was that of exploitation and colonization. Yugoslavia was against the Soviet Union, against the unique socialist camp and consequently against us"( On joint associations,1948).

According to the Yugoslavs, it was necessary that these associations had a central connection and this role would be carried out by the Coordination Commission, which would function as a common economic government (General Directorate of Archives, 1996). The agreement was respectively signed by the Albanian Minister of Economy Nako Spiru and the Yugoslav Minister of Commerce and Supplies Nikolla Petrovic.

The newspaper "Luftetari" continues: "The Coordination Commission of the economic plans aimed at achieving the de facto and de jure unification of our economies and effaced the economic independence of Albania, assuming in this way the economic direction of the state." (Coordination Commission for economic plans, 1948)

Consequently, the Treaty of Friendship and Mutual Assistance between Albania and Yugoslavia was signed in July 1946. This Treaty definitely paved the way to the union of these two countries. It was welcomed by the Soviet Union, whereas the other countries reacted badly. The Turkish newspaper "Vakit", wrote on $5^{\text {th }}$ of June 1946, when the treaty was not signed yet, that Yugoslavia was following the policy of Mussolini, who wanted to dominate the Adriatic Sea and later all the Mediterranean Sea. Some Italian newspapers had such headlines: "Yugoslavia swallows up Albania", "Tito wants to dominate the Balkans, Albania has disappeared as a national state", "Albania in the bosom of the Yugoslav Federation" (Hoxha, 2013).

On 27 November 1946, Albania and Yugoslavia signed an Economic Convention. This Convention was signed by Nako Spiru (Albanian Minister of Economy), and by Boris Kidric (member of the Yugoslav Politburo who was charged with the Yugoslav economy from 1946 until his death). Qualified as the "great economic agreement," it predicted the coordination of the economic plans, the customs union and the reconciliation of the currency. According to the convention, the Albanian currency "Lek" would be invalidated to the value of the Yugoslav currency "dinar", Albania would adjust the prices under the Yugoslav system of prices, the customs at the borders between these two countries would be abolished, there would be created a unique customs territory which would use the systems and the customs tariffs that were implemented in Yugoslavia. (Dedijer,1949).

The more Yugoslav efforts for domination of the Balkans increased, in particular the pressure on the Albanian state, the more the power of Enver Hoxha at the head of the Albanian state was threatened, thus he sought the support of the Soviet Union, whose government followed the situation in Balkans with concern.

Reconciliation of Currency was opposed in principle by the Albanian government despite numerous pressures of the Yugoslavs. According to the Albanian government, the currency union would be fictitious, because there were many practical obstacles to equalize "Lek" to "dinar". Regarding this matter the journal "Luftetari" carries on: "Specifically advised and supported by Soviet comrades, we have been against this monetary reform even after the Convention was signed (Reconciliation of currency, 1948). This monetary reform would cause a situation of no confidence in our currency, would create major upheaval to the country's economy and price increases would cause great inconveniences to the private sector. But the private sector included the agriculture as well. Agriculture was not a Yugoslav concern at all. They considered these concerns as a lack of trust in the agreements and as an objection towards practical implementation of the Economic Convention (Reconciliation of currency, 1948).

Immediately the Albanian economy began to face serious consequences. Gogo Nushi (Member of the Political Bureau), in the 1-st Congress of CPA, mentioned that 1 Albanian franc was equal to 12.5 dinar, which meant that, the Albanian economy was damaged 12.5 times ("Bashkimi" Newspaper, 1948). 
Anyway, Yugoslavs did not accept the rate of exchange 1 franc to 12.5 dinars, so they required determining a lower rate. But, assigning a lower rate would damage our economy; would weaken the value of our currency and reduce the purchasing power of people. Obviously a lower rate was convenient for the Yugoslav leadership because a lower rate meant a lower purchasing power; even the increase of salaries would be fictitious because in reality the salaries would decrease due to the low value of currency. The printing press of the time wrote that: "According to the study that Yugoslavs had allegedly conducted regarding the prices and cost of life in our country comparing this with Yugoslavia the rate of exchange should be 1 franc to 8 dinars" (Unification of Prices, 1948). The Albanian government did not agree with this rate and later on due to their insistence and as result of objections from Yugoslavs both parties agreed that the rate would be 1 franc to 9 dinars. Thus, the agreement on the exchange rate issue obviously was disadvantageous for us (Unification of Prices, 1948).

Part of the Economic Convention was also the customs union of Albania and Yugoslavia, a process which was seen from different perspectives. With the customs union, Albanian government meant a relief for the exchange of goods between the two countries without a customs duty between the two countries. This would help for the commodity exchange as well as the prices would be fixed according to the government policy and state budget needs. While the intention of Yugoslav customs union was to open borders and "fair" enterprises or commercials, as Yugoslavs described them, could come across Albanian cities and buy products with a cheap price and sell them in Yugoslavia (Customs Union, 1948). Thus the Yugoslav interests in the Economic Convention were obvious; they wanted to exploit as far as they could the Albanian market and assets and give minimum and insignificant things in exchange. The economic dependence on the Yugoslav state, was creating conditions for Albania to lose its political independence and sovereignty. Albanian history offered such typical examples before World War II.

The same paper, "Luftetari", approaches to the issue in this way: "Even without having a clear view of the dark purposes of CPY, our government considered the issues of currency reconciliation and unification of prices as unfair; these are very important and principal issues that later showed how fair our proposals were and which were the goals of Trotskyite Yugoslav leadership" (How were created and developed our relations with Yugoslavia and what were the goals of Trotskyite leadership of Yugoslav Communist Party over our country, 1948).

That was a further step that marked the loss of Albanian independence. This was even testified by a saying of the soviet adviser of the Plan Commission in 1947. When he saw the low figures of import-export between Albania and Yugoslavia, he said that: "They (thus the Yugoslavs) have taken from you everything that you have got and do not give you anything" ("Standard" Newspaper, 2011).

The text of the Economic Convention was not published at the time it was signed, but was made known to the public after split up with Yugoslavia, through the denunciations that the communists were charging on each other (Zavalani, 1998). Nako Spiru, who participated in the conclusion of the agreement, understood very well the "rope effect" that it would have on Albania's throat and despite this, as a signatory of the agreement, he was the direct responsible person towards the history for submission of the independence of the country with a free will (Hoxha,2013).

Six common associations were created in Albania, not with common capitals but on the basis of Albanian capitals. The Yugoslav party received its benefits without making any investment. An increasing pro-Yugoslav propaganda was conducted in our country, which was even reflected in the programs of Radio Tirana. The implementation of the above agreements faced huge difficulties. The Yugoslav government tried to guide the Albanian economy into the Yugoslav market function and to its economic development model. On the other hand, even the Yugoslavs borrowed the soviet model of the organization of the economy, and imposed it completely alike even on Albania. Meanwhile, the implementation of the signed agreements faced more and more obstacles; at that time, a great variety of Albanian products such as: olive oil, soap (Central State Archive,1945), oil, petroleum (Central State Archive,1945), wood, leather, herbs (Central State Archive,1946), fish (Central State Archive,1947), etc. were leaving the country. Shkoder supplied Montenegro with cement (Central State Archive,1947), but the supplies with the promised materials by the Yugoslav party did not come regularly and at the proper amount, disbursement of aids as well as the financial loans left much to be desired. The Yugoslav party did not respect the promised supplies toward Albania, as in the case of 300 tons of canned meat (Central State Archive,1947).

The climax of all this was when Belgrade, in May 1947, demanded possession of the properties owned by the Albanians who were sentenced in Yugoslavia as "war criminals". These people were mainly Albanian, former Yugoslav citizen who had different state responsibilities in Albania during the wartime (Central State Archive, 1947). In 1947, foreign trade volume of the Albanian state was the highest in those three years, even compared to 1938 (Fishta \& Ziu, 2004).

Actually, the heavy economic situation of Albania was also due to the economic reforms of the government, which consisted in the demolition of the existing economic structures. Until 1947, the market supply with the necessary food 
commodities was mainly as a result of the big stocks that were found from the war in Albania, than as a result of the internal manufacturing of that period.

In such circumstances, Nako Spiru, minister of economy, after being consulted with Enver Hoxha, asked the Yugoslav government to respect the signed agreements, at least as they were. However, the requirements of Nako Spiru created inconvenience for the Yugoslav leadership, because they interfered in Yugoslav's plans for a quick merging of Albania and Yugoslavia. At the end of June 1947, Yugoslavs, for the first time, officially complained that an anti-Yugoslav line in the Albanian leadership was crystallizing. In order to avoid the Yugoslav pressure, which at first aimed at his removal from leadership, Enver Hoxha insisted and in July 1947 achieved to pay an official visit in Moscow and meet Stalin. This visit was postponed several times, because of the Yugoslav leadership intervention, which did not want to allow a direct connection of Enver Hoxha with soviet leaders. Enver Hoxha went to Moscow to ensure a support and economic aid but also to strengthen his position.

In November 1947, the Central Committee of Yugoslav Communist Party conveyed to the Albanian Communist Leadership the second charge, which among other things noted that an anti-Yugoslav position and orientation was crystallizing in Albania. According to them, at that moment it was necessary to analyze the causes that made these relations unsatisfactory. In the letter of Belgrade, Nako Spiru was made responsible for the difficulties caused in the relations between these two countries. At the end Yugoslavs demanded the fulfillment of the requirements; otherwise they would be obliged to reconsider the economic agreements with Albania. Nako Spiru, situated in front of serious charges and without the support of the Political leadership, abandoned even by the soviets, on 20 November 1947, committed a suicide. Some days after this incident, the thesis of Central Committee of Yugoslav Communist Party, regarding the economic union between two countries which would later enable the creation of the Balkan Federation arrived in Tirana. Political leadership of the Albanian Communist Party approved the Yugoslav proposals, which posed a risk to the Albanian Independence.

In June 1948, Albanian government asked for a revision of all the signed agreements with Yugoslavia. Since the Yugoslav government opposed this request, the Albanian government invalidated these agreements. At the end of 1948, relations between two countries were at the lowest level.

In order to maintain the political leadership, Enver Hoxha had to negotiate with the Yugoslavs, but he was not ready to share the power neither with Yugoslavs nor with the pro -Yugoslav people in Albania. When this wing was getting stronger in the Albanian government, it was also the moment for the big disunion. The disruption of the relations between Tito and Stalin, in 1948, was the appropriate moment for Enver Hoxha, to face the Yugoslavs and even expel out of the game Koci Xoxe, a political competitor who was highlighted as "Yugoslavs man". During a conversation of K.Xoxe with Mr. Cuvahini (USSR envoy to Albania), extracted from the latter's diary, Xoxe feelingly said that: "I am ready to give up my life in order to prove that I have never been an anti-soviet, I did not ever consciously betrayed the Soviet Union (Lauka\&Ymeri, 2006). After that, in Albania began the persecution of the pro-Yugoslav group within CPA headed by Koci Xoxe, whom the court sentence to death and other light sentences were given for a range of their associates.

In the first Congress of CPA, the Yugoslav-Albanian relations were already disrupted. E.Hoxha accused Yugoslavs that the aim of the Economic Convention was to subdue Albania and to make it a colony of Yugoslavia, to hit the Albanian economy and to impede the construction of socialism in Albania, to rob it and to isolate it from the Soviet Union (Hoxha, 2013).

Whereas, as regards the Coordination Commission, Enver Hoxha stated that: "it would efface de facto and de jure the economic independence of Albania, Yugoslavia would assume the planning of the Albanian economy, would disconnect from the Albanian government the common associations and would take under control even the Albanian ministries" (Hoxha, 2013).

Disruption of the Yugoslav-Albanian relations saved the small Albania from the economic and political swallow of the official Belgrade.

\section{References}

Bashkimi Newspaper. (1948, November 14).

Central State Archive of Albania. (1945). Fund.588, File.25

Central State Archive of Albania. (1945). Fund.588, File.26

Central State Archive of Albania. (1946). Fund.588, File.106

Central State Archive of Albania. (1947). Fund.588, File.49

Central State Archive of Albania. (1947). Fund.588, File.61

Central State Archive of Albania. (1947). Fund.588, File.7

Coordination Commission of Economic Plans. (1948, November 17). Luftetari Newspaper, no.285 
Customs Union. (1948, November 17). Luftetari Newspaper, no. 285.

Dedijer, V. (1949). Yugoslav-Albanian Relations 1939-1948. Belgrade: PROSVETA.

Fishta, I. \& Ziu, M. (2004). Economic History of Albania 1944-1960. Tirana: DITA.

General Directorate of Archives. (1996). Yugoslav-Albanian Relations 1945-1948. Tirana: GDA.

How were created and developed our relations with Yugoslavia and what were the goals of Trotskyite leadership of Yugoslav Communist Party over our country. (1948, November 17). Luftetari Newspaper, no. 285.

Hoxha, C. (2013). The Beginning of Communist Dictatorship in Albania 1944-1948. Tirana: WEST PRINT.

Lauka, I. \& Ymeri, E. (2006). Eastern Europe in Russian archive documents 1944-1953. Tirana: TOENA.

On Joint Associations. (1948, November 17). Luftetari Newspaper, no.285.

Plasari, N. \& Malltezi L. (1996). Yugoslav-Albanian Relations 1945-1948. Tirana: GDA.

Reconciliation of Currency. (1948, November 17). Luftetari Newspaper, no.285.

Standard Newspaper. (2011, August 7).

Unification of Prices. (1948, November 17). Luftetari Newspaper, no. 285.

Zavalani, T. (1998). History of Albania, Tirana: PHOENIX \& SHTEPIA E LIBRIT. 